\title{
Effect of grazing and cultivation on some chemical proper- ties of soils in the mixed prairie
}

\author{
JOHAN F. DORMAAR AND WALTER D. WILLMS
}

\begin{abstract}
Components of the organic matter were studied in soil under 3 Mixed Prairie types: grassland dominated by needle-and-thread/blue grama (Stipa comata Trin. and Rupr./Bouteloua gracilis (HBK.) Lag. ex Steud.) in good range condition; grassland significantly modified by grazing, dominated by blue grama and in poor range condition; and grassland, dominated by needle-and-thread/blue grama in good range condition, but converted to cropland and under continuous wheat for 4 years. The soils were sampled on 13 April 1988. Concentrations of total organic carbon in the upper 2 $\mathrm{cm}$ were $1.39,2.70$, and $1.87 \%$, respectively. The higher organic carbon under blue grama was caused by an active, ramified, fine rootmass which gave rise to most of the monosaccharides being of microbial origin. The monosaccharides in the lower Ap horizon in the cropland were generally of plant origin from incorporated straw.
\end{abstract}

The Ah horizons of the needle-and-thread/blue grama and blue grama sites and the Ap horizon of the cultivated site yielded 244, 696 , and $370 \mu \mathrm{g} \cdot \mathrm{g}^{-1}$ organic acids in the alkaline-soluble fraction of the soil, respectively. Although most of the organic compounds identified were present in all 3 soils, the quantitative patterns were quite different. Differences exist due to inputs by different species, and 4 years of cropping also made significant soil chemical changes. This study demonstrated the importance of recognizing the history of the soils studied when describing soil quality.

Key Words: Chernozemic, soll quality, soll transformations, comparison standards

The quality of soil organic matter is sensitive not only to changes in parent material and plant cover, but also to management of the vegetation (Russell 1961). The long-term effects of grazing by sheep on Stipa-Bouteloua prairie in Alberta (Smoliak et al. 1972) were a decrease in $\mathrm{pH}$ and percentage basal area of needle-andthread (Stipa comata Trin. and Rupr.), and an increase in total C, solvent-extractable $C$, alkaline-soluble $C$, polysaccharides, and percentage basal area of blue grama (Bouteloua gracilis (HBK.) Lag. ex Steud) and little club-moss (Selagenella densa Rydb.). An assessment of the recovery of the vegetative cover on abandoned farmland and concomitant soil characteristics under semiarid climatic conditions indicated that, under moderate grazing by livestock, more than 55 years were required for soil to return to native range standards (Dormaar and Smoliak 1985).

Since the sheep grazing experiment was terminated in 1969 , most of the area has been plowed up and reseeded. However, the reseeding was unsuccessful and the field was abandoned to allow for the recovery of the native vegetation. One part of the field was spared this fate to allow various other studies (Dormaar et al. 1977, Dormaar et al. 1981). The pure stands of blue grama have persisted over the years.

The purpose of this study was to examine the organic composition of soil under a Stipa-Bouteloua faciation in an exclosure, as compared to the enduring effect on the soil of a Bouteloua disclimax, and the effect of recent cultivation on the soil. Blue grama seems to maintain itself as a disclimax dominant by resisting the

\footnotetext{
Authors are scientist and range ecologist, respectively, Agriculture Canada Research Station, Lethbridge, Alberta T1J 4Bi. Contribution No. 3878918.

Technicians R.R. James and T. Connolly assisted with the laboratory analyses.

Manuscript accepted 8 February 1990.
}

establishment of the other species. The soil organic matter of semiarid regions is sensitive to anthropogenic pressure (Dormaar et al. 1977).

\section{Materials and Methods}

\section{Sampling Sites}

Three sites geographically separated by several kilometers but still within the Mixed Prairie (Coupland 1961) and with similar parent material were sampled 13 April 1988. Site 1 represented vegetation typical of the Stipa-Bouteloua faciation of the Mixed Prairie Association in an ungrazed exclosure. Site 2 represented a Mixed Prairie area that had been overgrazed by sheep for 19 years, and where blue grama and little club-moss had increased to being the dominant species. Presently, Site 2 is being moderately grazed by cattle. Site 3 represented a field broken out of Mixed Prairie in 1984 and under continuous wheat since that time with a biennial application of between 22 and $56 \mathrm{~kg}$ of $\mathrm{N}$, and 0 and $17 \mathrm{~kg} \mathrm{P}_{2} 0_{5}$ per hectare, as recommended (Alberta Agriculture 1984) for the area.

\section{Soils}

The soils of all 3 sites are members of the Orthic Brown Subgroup of the Chernozemic Order (Aridic Ustochrept) on till with loam texture. The climate is semiarid with an average annual precipitation of $310 \mathrm{~mm}$. At each site, the $A$ horizon from 0 to $2 \mathrm{~cm}$ $\left(A h_{1}\right.$ or $\left.A P_{1}\right)$ and from $2 \mathrm{~cm}$ to the bottom of the $A$ horizon $\left(A h_{2}\right.$ or $\mathrm{AP}_{2}$ ) and the whole $\mathrm{Bm}$ horizon were sampled within 3 subplots in each of the 3 sampling plots. The latter were about $100 \mathrm{~m}$ apart. The subplot samples were combined, mixed, hand-sieved through a $20-\mathrm{mm}$ sieve, and stored in sealed, double polyethylene bags at $4^{\circ}$ C. At the time of sieving, roots and other debris were removed from the soil and discarded. Moisture content of the soils was determined by drying a small portion overnight at $105^{\circ} \mathrm{C}$. After the mineralizable $\mathrm{N}$ and dehydrogenase activity analyses were carried out, the soils were dried and ground to pass a $0.5-\mathrm{mm}$ sieve.

\section{Analyses}

Soil $\mathrm{pH}$ was measured in $0.01 \mathrm{M} \mathrm{CaCl}_{2}$ (solution: soil ratio of 2:1). Total $\mathrm{C}$ and $\mathrm{N}$ were determined by dry combustion in a Carlo Erba NA 1500 Analyzer, carbonates were eliminated with $\mathrm{HCl}$ prior to the analysis. The biological index of $\mathrm{N}$ availability (mineralizable $\mathbf{N}$ ) was determined as outlined by MacKay and Carefoot (1981); the chemical index of $\mathrm{N}$ availability (autoclaveable $\mathrm{N}$ ) was determined as outlined by Keeney (1982). Exchangeable $\mathrm{NO}_{\overline{3}}-\mathrm{N}$ and $\mathrm{NH}_{4}^{+}-\mathrm{N}$ were determined by steam distillation as outlined by Keeney and Nelson (1982). $\mathrm{NaHCO}_{3}$-soluble $\mathrm{P}$ was determined as per Olsen et al. (1954).

Within $24 \mathrm{~h}$ after the soils were sampled, dehydrogenase activity of the fresh, moist soil was determined at $\mathrm{pH} 7.6$ by measuring the triphenylformazan (formazan) produced by reduction of 2,3,5,-triphenyltetrazolium chloride when soil was incubated with 2-amino2-(hydroxymethyl)propane-1:3 diol buffer $(0.5 \mathrm{M})$ at $30^{\circ} \mathrm{C}$ for $5 \mathrm{~h}$ (Ross 1971). Carbohydrates were determined by the phenolsulfuric acid method of Dubois et al. (1956) as modified by Doutre et al. (1978). The monosaccharide distribution in hydrolysates of the soil samples was assessed as outlined by Dormaar $(1984,1987)$. The quantitative analyses of the alditol acetates were done with a Hewlett Packard GC 5840A. 
Table 1. Some chemical characteriatics of soil from needle-and-thread/blue grama range, blue grama range, and cropland (average of 3 samples).

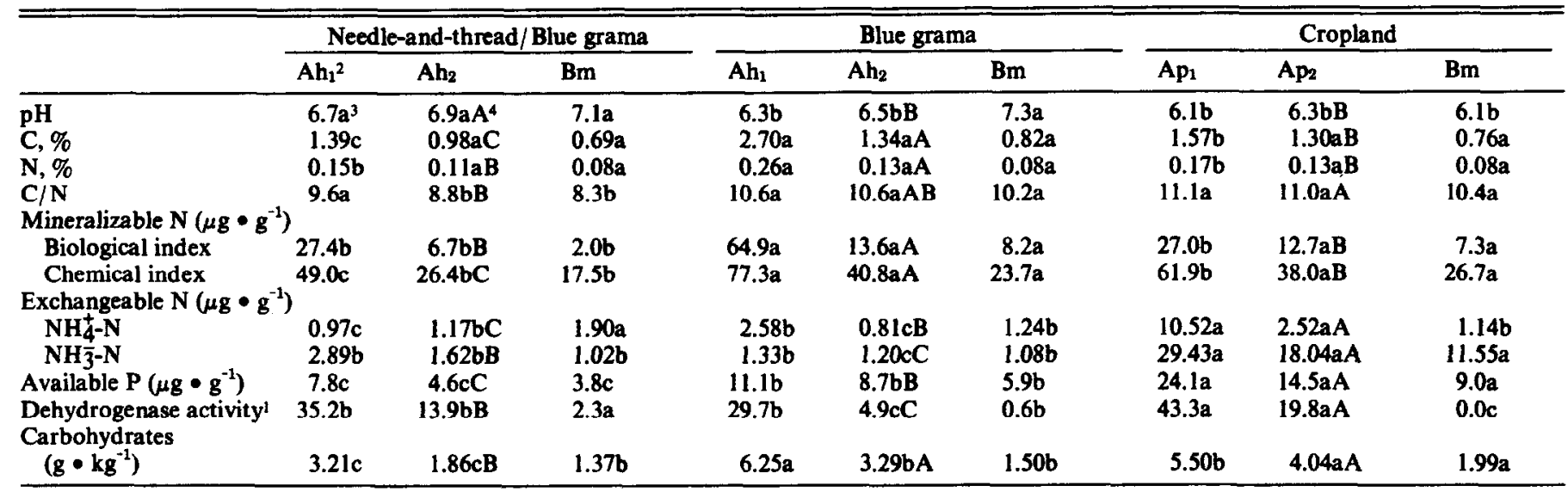

'Formazan released, nmol $\bullet g^{-1}$ dry soil per hour.

${ }^{2} \mathrm{Ah}_{1} / \mathrm{Ap} \mathrm{p}_{1}$-upper $2 \mathrm{~cm}$ of $\mathrm{A}$ horizon; $\mathrm{Ah} \mathrm{h}_{2} / \mathrm{Ap}$-remainder of $\mathrm{A}$ horizon.

$3 a-c$ Means followed by the same letter within a horizon, e.. ., $A h_{1}$ vs. A $A h_{1}$ vs. $A p_{1}$, are not significantly different $(P>0.05)$.

$4 \mathrm{~A}-\mathrm{C}$ Means followed by the same letter within the $A h_{1}+\mathbf{A h} \mathbf{h}_{2}$ and $A p_{1}+A p_{2}$ horizons are not significantly different $(P>0.05)$.

To obtain alkaline-soluble organic acids (Morita 1965, Vance et al. 1985 , Whitehead et al. 1975), $10 \mathrm{~g}$ of soil was hydrolyzed under $\mathrm{N}_{2}$ with $100 \mathrm{~mL} 0.5 \mathrm{M} \mathrm{NaOH}$ by shaking for $18 \mathrm{~h}$, after which the mixture was centrifuged and the supernatant decanted. Another $100 \mathrm{~mL}$ of $1.0 \mathrm{M} \mathrm{NaOH}$ was added to the soil, heated under $\mathrm{N}_{2}$ in a $90^{\circ} \mathrm{C}$ waterbath for $4 \mathrm{~h}$, cooled, centrifuged, and the supernatant decanted. Finally, the soil was twice washed with $50 \mathrm{~mL}$ distilled water. The 2 supernatants and 2 washings were combined, acidified to $\mathrm{pH} 2.0$ with $2 \mathrm{M} \mathrm{HCl}$, and centrifuged. The supernatant was treated with a $40-\mathrm{mL}$ suspension of freshly precipitated $\mathrm{Zn}_{2} \mathrm{Fe}(\mathrm{CN})_{6}$ (15 mL/100 mL extract) to precipitate lipid material (Hamence 1944).

The treated supernatant was readjusted to $\mathrm{pH} 2.0$, centrifuged to remove a brown precipitate, and filtered by vacuum through a Buchner funnel (Whatman \#5). The filtrate was centrifuged and filtered once more after which the filtrate was extracted 3 times with ethyl acetate in a separatory funnel. The combined ethyl acetate extract was dried over anhydrous $\mathrm{Na}_{2} \mathrm{SO}_{4}$ before being partitioned by washing 4 times with equal volumes of $8 \% \mathrm{NaHCO}_{3}$ solution. This procedure was designed to transfer the organic acids to the aqueous phase (Jalal and Read 1983). The $\mathrm{NaHCO}_{3}$ solution was acidified to pH 2.0 and re-extracted 4 times with $15 \%$ ethyl acetate. The combined organic phase was reduced to $5 \mathrm{~mL}$ on a rotary evaporator $\left(48^{\circ} \mathrm{C}, 20 \mathrm{kPa}\right)$.

The solution was transferred into a small vial, evaporated to dryness with a stream of $\mathrm{N}_{2}, 200 \mu \mathrm{L}$ of pyridine, containing 3methoxybenzoic acid at a concentration of $0.5 \mu \mathrm{g}$ per $\mu \mathrm{L}$ to serve as internal standard, added and mixed. To obtain silylation (Jalal and Read 1983; Pierce Chemical Company 1985), $200 \mu$ L N,O-bis(trimethylsilyl)trifluoroacetamide (BSTFA) were added and mixed. To ensure complete derivatization, the sample mixture was heated at $60^{\circ} \mathrm{C}$ in the closed vial for $10 \mathrm{~min}$.

The quantitative analyses were carried out with a Hewlett Packard GC 5840A, using a 30-m long capillary column wall-coated with 5\% diphenyl $195 \%$ dimethyl polysiloxane (DB-5). The qualitative analyses were carried out with a Hewlett Packard 5985B. Tentative identifications were based on the search of the GC-MS data system and, where possible, authentic samples.

Each chemical constituent was analyzed across site for each sampling depth using analysis of variance with 2 and $6 \mathrm{df}$ for site and error terms, respectively. The plot variation was assumed to represent the experimental error since true replication was not

Table 2. Monosaccharide (as acetates) composition ( $\mathrm{mg} \bullet \mathrm{kg}^{-1}$ ) of hydrolysates of soil from needle-and-thread/blue grama range, blue grama range, and cropland (average of 3 subsamples).

\begin{tabular}{|c|c|c|c|c|c|c|c|c|c|}
\hline & \multicolumn{3}{|c|}{ Needle-and-thread/Blue grama } & \multicolumn{3}{|c|}{ Blue grama } & \multicolumn{3}{|c|}{ Cropland } \\
\hline & $\mathrm{Ah}_{1}{ }^{1}$ & $\mathbf{A h}_{2}$ & $\mathrm{Bm}$ & $\mathrm{Ah}_{1}$ & $\mathrm{Ah}_{2}$ & $\mathrm{Bm}$ & $\mathrm{Ap}_{1}$ & $\mathbf{A p}_{2}$ & $\mathrm{Bm}$ \\
\hline $\begin{array}{l}\text { 1. Rhamnose } \\
\text { 2. Fucose } \\
\text { 3. Ribose } \\
\text { 4. Arabinose } \\
\text { 5. Xylose } \\
\text { 6. Mannose } \\
\text { 7. Galactose } \\
\text { 8. Glucose }\end{array}$ & $\begin{array}{c}98 \mathrm{a}^{2} \\
62 \mathrm{a} \\
19 \mathrm{a} \\
228 \mathrm{~b} \\
119 \mathrm{~b} \\
58 \mathrm{a} \\
188 \mathrm{a} \\
41 \mathrm{~b}\end{array}$ & $\begin{array}{c}24 \mathrm{aA}^{3} \\
26 \mathrm{aA} \\
8 \mathrm{aA} \\
48 \mathrm{aB} \\
9 \mathrm{bC} \\
11 \mathrm{bA} \\
29 \mathrm{aA} \\
14 \mathrm{bB}\end{array}$ & $\begin{array}{l}8 \mathbf{a} \\
6 \mathrm{a} \\
1 \mathrm{a} \\
7 \mathrm{a} \\
1 \mathrm{~b} \\
1 \mathrm{~b} \\
3 \mathrm{a} \\
3 \mathrm{a}\end{array}$ & $\begin{array}{r}64 b \\
26 c \\
12 b \\
414 a \\
288 a \\
17 c \\
165 a \\
54 b\end{array}$ & $\begin{array}{r}19 \mathrm{aB} \\
8 \mathrm{bC} \\
5 \mathrm{aB} \\
11 \mathrm{bA} \\
9 \mathrm{bA} \\
3 \mathrm{cC} \\
33 \mathrm{aA} \\
3 \mathrm{cB}\end{array}$ & $\begin{array}{l}5 b \\
3 b \\
1 a \\
3 b \\
2 a \\
1 b \\
2 a \\
1 b\end{array}$ & $\begin{array}{c}69 \mathrm{~b} \\
51 \mathrm{~b} \\
15 \mathrm{ab} \\
172 \mathrm{c} \\
137 \mathrm{c} \\
42 \mathrm{~b} \\
179 \mathrm{a} \\
72 \mathrm{a}\end{array}$ & $\begin{array}{c}18 \mathrm{aB} \\
8 \mathrm{bB} \\
6 \mathrm{aAB} \\
11 \mathrm{bC} \\
18 \mathrm{aB} \\
17 \mathrm{aB} \\
38 \mathrm{aA} \\
27 \mathrm{aA}\end{array}$ & $\begin{array}{l}1 c \\
2 b \\
2 a \\
1 c \\
3 a \\
4 a \\
2 a \\
3 a\end{array}$ \\
\hline $\begin{array}{l}\text { Deoxyhexoses }(1+2) \\
\text { Pentoses }(3+4+5) \\
\text { Hexoses }(6+7+8) \\
\text { Total }\end{array}$ & $\begin{array}{l}160 \\
366 \\
287 \\
813\end{array}$ & $\begin{array}{r}50 \\
65 \\
54 \\
169\end{array}$ & $\begin{array}{r}14 \\
9 \\
7 \\
30\end{array}$ & $\begin{array}{r}90 \\
714 \\
236 \\
1040\end{array}$ & $\begin{array}{l}27 \\
25 \\
39 \\
91\end{array}$ & $\begin{array}{r}8 \\
6 \\
4 \\
18\end{array}$ & $\begin{array}{l}120 \\
324 \\
293 \\
737\end{array}$ & $\begin{array}{r}26 \\
35 \\
82 \\
143\end{array}$ & $\begin{array}{r}3 \\
6 \\
9 \\
18\end{array}$ \\
\hline$(7+6):(4+5)$ & $0.72 \mathrm{a}$ & $0.70 \mathrm{bB}$ & $0.50 \mathrm{~b}$ & $0.26 \mathrm{~b}$ & $1.80 \mathrm{aA}$ & $0.60 \mathrm{~b}$ & $0.72 \mathrm{a}$ & $1.90 \mathrm{aA}$ & $1.50 \mathrm{a}$ \\
\hline
\end{tabular}

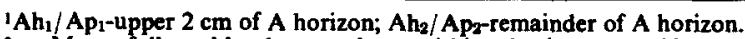

${ }_{2 a-c}$ Means followed by the same letter within a horizon, e.g., $A h_{1}$ vs. A $h_{2}$ vs. Ap are not significantly different $(P>0.05)$.

3A-C Means followed by the same letter within the $A h_{1}+A h_{2}$ and $A p_{1}+A p_{2}$ horizons are not significantly different ( $P>0.05$ ). 
Table 3. Tentatively identified organic acids in the $\mathrm{NaOH}$-soluble fraction from Chernozemic Ah, Ap, and Bm horizons as determined by GC-MS.

\begin{tabular}{ll}
\hline \hline Peak no. & \multicolumn{1}{c}{ Compound } \\
\hline 1. & Benzoic acid' \\
2. & Succinic acid (butanedioic acid ) \\
3. & Fumaric acid (butenedioic acid) \\
4. & Glutaric acid (pentanedioic acid) \\
5. & Hydrocinnamic acid (benzenepropanoic acid) \\
6. & p-Hydroxybenzoic acid \\
7. & Phthalic acid (1,2-benzenedicarboxylic acid) \\
8. & Atrolactic acid (a-hydroxy-2-methylbenzeneacetic acid) \\
9. & Vanillic acid (4-hydroxy-3-methoxybenzoic acid) \\
10. & Azelaic acid (nonanedioic acid) \\
11. & Protocatechuic acid (3,4-dihydroxybenxoic acid) \\
12. & Syringic acid \\
13. & p-Coumaric acid (3-(4-hydroxyphenyl)-2-propenoic acid) \\
14. & Fatty acid 16:0 (hexadecanoate) \\
15. & Ferulic acid (3-(4-hydroxy-3-methoxyphenyl)-2-propenoic acid) \\
16. & Fatty acid 20:0 (eiocosanoate) \\
17. & Bis(2-ethylhexyl)phthalate (1,2-benzenedicarboxylic acid \\
18. & bis(2-ethylhexyl)ester) \\
\hline
\end{tabular}

ITitle as listed by Windholz et al. (1983).

${ }^{2}$ Name corresponding to that used by Chemical Abstracts Service.

possible. Specific comparisons were made using Scheffe's test (Steel and Torrie 1980).

Repeated samplings of a single plot will reduce variance attributable to analytical or sampling errors and do not constitute a replication of an applied treatment. It is also recognized that chemical and vegetational changes that may occur within and on the soil are undoubtedly affected by a host of environmental effects that vary with years. Ideally, the most accurate assessment of such changes would be made from repeated analyses of samples taken periodically from replicated treatements over many years. Although replication is undeniably desirable and useful, valid information and data can still be gained from early established, unreplicated field experiments, including long-term grazing trials, by virtue of their antiquity (Ridley and Hedlin 1968, Dormaar and Pittman 1980). Finally, it has been shown (Dormaar 1964, Dormaar and Smoliak 1985) that samples taken from Chernozemic soils in southeastern Alberta with similar parent material and vegetation within a Soil Zone, were statistically similar. Any differences between Sites 1,2 , and 3 are thus assumed to be due to treatment and not to random variability.

\section{Results}

\section{Chemical Characteristics}

When comparing the needle-and-thread/blue grama, blue grama, and cropland soils, i.e., under either grassland or cropland cover (Table 1), all $A h_{1}$ vs. $A h_{1}$ vs. $A p_{1}$ and $A h_{2}$ vs. Ah $h_{2}$ vs. Ap comparisons differed significantly $(P<0.01)$ except for one $C$ and one $C / N$ ratio comparison which were not significant $(P>0.05)$. However, when the $A h_{1}+A h_{2}$ vs. $A h_{1}+A h_{2}$ vs. $A p_{1}+A p_{2}$ were analyzed together, the $\mathrm{C}$ and $\mathrm{C} / \mathrm{N}$ ratio comparisons became significant $(P<0.05)$ as well. Only total $\mathrm{C}$ and $\mathrm{N}$ did not differ significantly $(P>0.05)$ among sites in the $\mathrm{Bm}$ horizon. The blue grama and cropland sites should really be compared individually, rather than collectively, with the needle-and-thread/blue grama site. The change from needle-and-thread/blue grama to cropland increased the $\mathbf{C}$ content, the chemical index, dehydrogenase activity, and carbohydrate content of the A horizon (Table 1). In comparison with the $A h_{1}$ of the needle-and-thread/blue grama site, the $\mathrm{C}$ content almost doubled under blue grama. This increase was due to the root mass distribution of the blue grama (Smoliak et al. 1972;
Table 2). The exchangeable $N$ and available $P$ values were highest in the cropland soil because of the fertilizers used, whereas mineralizable $\mathrm{N}$ was generally highest in the blue grama soil. Dehydrogenase activity was highest in the $A h_{1}$ and $A h_{2}$ horizons of the cropland soil but lowest, i.e., nonmeasurable, in its BM soil.

\section{Monosaccharides}

The 8 monosaccharides detected were present at each site but often in significantly $(P<0.05)$ different proportions (Table 2$)$. The 3 dominant sugars were arabinose, xylose, and galactose. The $\mathrm{Ah}_{1}$ of the needle-and-thread/blue grama soil had the most deoxyhexoses (rhamnose + fucose), the $A h_{1}$ of the blue grama soil had the most pentoses (ribose + arabinose + xylose), and the $A h_{1}$ of the cropland and needle-and-thread/blue grama soils were highest in hexoses (mannose + galactose + glucose). The levels of all monosaccharides decreased rapidly below $2 \mathrm{~cm}\left(\mathrm{Ah}_{2}\right)$. Most of the differences between the same horizons were significant.

Another way to present the data was to calculate the ratio of galactose + mannose to arabinose + xylose. This ratio was close to 2.0 for the $A h_{2}$ horizons of the blue grama and cropland soils and the $\mathrm{Bm}$ of the cropland soil. The other horizons had values less than $1.0 ; \mathrm{Ah}_{1}$ of the blue grama soil was only 0.26 .

\section{Organic Acids}

Seventeen acids were tentatively identified (Table 3). One acid, although prominent particularly in the cropland $\mathrm{Ah}_{1}$ and $\mathrm{Ah}_{2}$ horizons, was not identified. Although there are many individual differences, the $A h_{1}$ horizon of the blue grama soil contained a total of $542 \mu \mathrm{g}$ of organic acids $\bullet \mathrm{g}^{-1}$ of soil compared with 251 and $163 \mu \mathrm{g} \bullet \mathrm{g}^{-1}$ of soil for the cropland and needle-and-thread/blue grama soils, respectively (Table 4). Several acids, such as hydrocinnamic acid (peak 5) and atrolactic acid (peak 8) in the $A h_{1}$ of the blue grama soil, were prominent in all $\mathrm{Ah}_{1}$ horizons. Other prominent acids were benzic acid (peak 1), azelaic acid (peak 10), pcoumaric acid (peak 13), fatty acid 20:0 (peak 16), and bis(2ethylhexyl)phthalate (peak 17).

\section{Discussion}

The change from needle-and-thread/blue grama prairie to a grass cover predominantly consisting of blue grama took 19 years to establish at site 2 (Smoliak et al. 1972). The blue grama has endured since grazing ceased. Although long-term cultivation is known to change many soil chemical properties (Russell 1961), as little as 4 years of cropping can also initiate such changes. Although part of these latter changes will be caused by the mixing effects of cultivation, the lower sugar levels in the cropland soil are not surprising because there was no root exudate input into the system for part of the year. Further, the equilibrium under which soil organic matter of the needle-and-thread/blue grama exists is easily altered (Doughty 1948, Smoliak et al. 1972).

Practically all the $\mathbf{N}$ in surface soils is organically combined (Keeney 1982). A significant amount of this soil organic $\mathrm{N}$ is mineralized during a growing season. Laboratory indices of $\mathbf{N}$ availability allow not only a measure of the soil's ability to release $\mathrm{N}$ for plant growth, but also insight into $\mathrm{N}$-organic matter relationships. Even though the biological indices of the cropland and needle-and-thread/blue grama sites were similar, the different chemical indices suggested that the organic matter quality is no doubt different. That is, the organic matter of the needle-andthread/blue grama soil was probably in a more stable humified stage than the organic matter from the cropland soil, particularly in the $\mathrm{Ah}_{1}$ of the blue grama is certainly of different quality. Since the chemical index is faster and easier to carry out than the biological index, it may be a good analysis to separate different types of organic matter on the basis of mineralizability of the organically bound $\mathbf{N}$. 
Table 4. Organic acids $\left(\mu_{\mathrm{g}} \bullet \mathrm{g}^{-1}\right)$ in the alkaline-soluble fraction of soil from needle-and-thread/blue grama, blue grama range, and cropland (average of 3 samples).

\begin{tabular}{|c|c|c|c|c|c|c|c|c|c|}
\hline \multirow[b]{2}{*}{ Peak No. } & \multicolumn{3}{|c|}{ Needle-and-thread/blue grama } & \multicolumn{3}{|c|}{ Blue grama } & \multicolumn{3}{|c|}{ Cropland } \\
\hline & $A h_{1}{ }^{2}$ & $\mathrm{Ah}_{2}$ & $\mathrm{Bm}$ & $\mathrm{Ah}_{1}$ & $\mathrm{Ah}_{2}$ & $\mathrm{Bm}$ & $\mathbf{A h _ { 1 }}$ & $\mathrm{Ah}_{2}$ & $\mathrm{Bm}$ \\
\hline 11 & $10.6 \mathbf{a}^{3}$ & $6.2 \mathrm{bA}^{4}$ & $26.4 a$ & $10.5 \mathbf{a}$ & $9.3 \mathrm{aA}$ & $5.4 b$ & $5.2 \mathrm{~b}$ & $6.1 \mathrm{bB}$ & $1.0 \mathrm{c}$ \\
\hline 2 & $6.5 \mathrm{~b}$ & $4.7 \mathrm{bB}$ & $8.5 \mathrm{a}$ & $3.3 \mathrm{c}$ & $2.6 \mathrm{cC}$ & $2.1 \mathrm{~b}$ & $8.9 a$ & $6.0 \mathrm{aA}$ & $3.5 b$ \\
\hline 3 & $2.4 a$ & $1.4 \mathrm{bB}$ & $2.9 \mathrm{a}$ & $2.9 \mathrm{a}$ & $13.1 \mathrm{aA}$ & Oc & $2.8 \mathrm{a}$ & $2.4 \mathrm{bB}$ & $0.9 \mathrm{~b}$ \\
\hline 4 & $\mathbf{0 b}$ & OaB & $3.2 \mathrm{a}$ & $2.3 \mathrm{a}$ & $0 \mathrm{aA}$ & $\mathbf{O b}$ & $1.9 \mathrm{a}$ & OaA & $0.4 \mathrm{~b}$ \\
\hline 5 & $15.5 \mathrm{c}$ & $0 \mathrm{cC}$ & $0 \mathrm{c}$ & $208.9 a$ & $45.1 \mathrm{aA}$ & $2.7 b$ & $53.5 \mathrm{~b}$ & $25.1 \mathrm{bB}$ & $5.8 \mathrm{a}$ \\
\hline 6 & $5.7 \mathrm{c}$ & $3.8 \mathrm{bc}$ & $1.9 \mathrm{c}$ & $10.2 \mathrm{a}$ & $8.9 \mathrm{aA}$ & $4.7 \mathrm{a}$ & $7.6 \mathrm{~b}$ & $5.4 \mathrm{bB}$ & $3.4 \mathrm{~b}$ \\
\hline 7 & $2.2 \mathrm{~b}$ & $1.8 \mathrm{bB}$ & $1.5 \mathrm{~b}$ & $9.5 \mathrm{a}$ & $4.2 \mathrm{aA}$ & $0 c$ & $9.2 \mathrm{a}$ & $5.2 \mathrm{aA}$ & $2.7 \mathrm{a}$ \\
\hline 8 & $41.1 \mathrm{~b}$ & $4.1 \mathrm{cB}$ & $7.7 \mathrm{a}$ & $183.3 \mathrm{a}$ & $30.8 \mathrm{aA}$ & $3.3 \mathrm{~b}$ & $28.3 c$ & $6.5 \mathrm{bC}$ & $2.5 c$ \\
\hline 9 & $5.1 \mathrm{a}$ & $2.2 \mathrm{bB}$ & $8.1 \mathrm{a}$ & $5.5 \mathrm{a}$ & $4.1 \mathrm{aA}$ & $2.6 \mathrm{~b}$ & $5.6 \mathrm{a}$ & $3.9 \mathrm{aA}$ & $2.4 b$ \\
\hline 10 & $15.2 \mathrm{c}$ & $4.6 \mathrm{bC}$ & $5.1 \mathrm{a}$ & $20.5 b$ & $10.5 \mathrm{aB}$ & $3.2 \mathrm{~b}$ & $25.9 \mathrm{a}$ & $11.3 \mathrm{aA}$ & $5.5 \mathrm{a}$ \\
\hline 11 & $1.8 \mathrm{~b}$ & $0 \mathrm{aB}$ & $1.3 \mathrm{~b}$ & $2.4 \mathrm{a}$ & OaA & $7.1 \mathrm{a}$ & $0 c$ & $0 \mathrm{aC}$ & $0.3 \mathrm{~b}$ \\
\hline 12 & $2.3 b$ & $2.7 \mathrm{aA}$ & $4.4 a$ & $3.9 \mathrm{a}$ & ObB & oc & $3.2 \mathrm{ab}$ & $2.6 \mathrm{aA}$ & $0.9 \mathrm{~b}$ \\
\hline 13 & $10.8 \mathrm{c}$ & $5.7 \mathrm{cC}$ & $2.1 b$ & $28.1 \mathrm{a}$ & $9.4 \mathrm{bA}$ & $4.9 \mathrm{a}$ & $19.6 \mathrm{~b}$ & $12.0 \mathrm{aB}$ & $4.5 \mathrm{a}$ \\
\hline 14 & $3.9 \mathrm{a}$ & $2.3 \mathrm{cA}$ & $5.5 a$ & $2.8 \mathrm{~b}$ & $2.8 \mathrm{bA}$ & $5.1 \mathrm{a}$ & $2.5 \mathrm{~b}$ & $3.5 \mathrm{aA}$ & $0.4 b$ \\
\hline 15 & $2.5 \mathrm{c}$ & $7.2 \mathrm{bB}$ & $1.6 \mathrm{~b}$ & $4.2 \mathrm{~b}$ & $0 c \mathrm{C}$ & $0 c$ & $15.5 \mathrm{a}$ & $11.8 \mathrm{aA}$ & $4.8 \mathrm{a}$ \\
\hline 16 & $18.2 b$ & $14.1 \mathrm{aB}$ & $3.8 \mathrm{a}$ & $12.2 \mathrm{c}$ & $2.6 \mathrm{bC}$ & $\mathbf{0 b}$ & $38.6 a$ & $3.2 \mathrm{bA}$ & $3.2 \mathrm{a}$ \\
\hline 17 & $16.1 \mathrm{~b}$ & $20.1 \mathrm{aB}$ & $7.4 \mathrm{a}$ & $28.9 a$ & $10.4 \mathrm{bA}$ & $4.4 \mathrm{~b}$ & $10.3 \mathrm{c}$ & $7.0 \mathrm{cC}$ & $3.1 \mathrm{~b}$ \\
\hline 18 & $3.1 \mathrm{~b}$ & $\mathrm{ObB}$ & $0 \mathbf{a}$ & $2.6 \mathrm{~b}$ & ObB & $0 \mathrm{a}$ & $12.4 \mathrm{a}$ & $6.5 \mathrm{aA}$ & $0 \mathrm{a}$ \\
\hline Total & 163.0 & 80.9 & 91.4 & 542.0 & 153.8 & 45.5 & 251.0 & 118.5 & 45.3 \\
\hline
\end{tabular}

${ }^{1}$ Compounds as tentatively identified in Table 3.

${ }^{2} \mathrm{Ah}_{1} / \mathrm{Ap}_{1}$-upper $2 \mathrm{~cm}$ of $\mathrm{A}$ horizon; $\mathrm{Ah} / \mathrm{Ap} \mathrm{p}_{2}$-remainder of $\mathrm{A}$ horizon.

${ }_{3 a-c}$ Means followed by the same letter within a horizon, e.g., $A h_{1}$ vs. $A h_{1}$ vs. $A p_{1}$, are not significantly different $(P>0.05)$.

${ }^{4} \mathrm{~A}-\mathrm{C}$. Means followed by the same letter within the $\mathrm{Ah} \mathrm{h}_{1}+\mathrm{Ah}_{2}$ and $\mathrm{Ap_{1 }}+\mathrm{Ap} \mathrm{p}_{2}$ horizons are not significantly different $(P>0.05$.

The carbohydrates in the soil are, for the most part, derived from plant polysaccharides in roots and plant debris with the remainder being derived from mucilages associated with roots and microorganisms. Polysaccharides containing substantial quantities of arabinose and xylose are considered to be of plant origin and those containing galactose and mannose to be predominantly of microbial origin (Oades 1984), and thus the ratio galactose + mannose/arabinose $+x y l o s e$ will be low $(<0.5)$ for plant polysaccharides and high $(>2.0)$ for microbial polysaccharides. The $\mathrm{Ah}_{1}$ of the blue grama soil does, therefore, seem to have more polysaccharides of microbial origin than any of the other horizons under either needle-and-thread/blue grama or cropland. This is in keeping with the organic $\mathrm{C}$ level (Table 1), derived mainly from root mass and root exudates as shown by growth chamber-grown blue grama (Dormaar 1988). While the ramified, active, fine root mass of blue grama in the $\mathrm{Ah}_{1}$ horizon has created a potential for the production of diffusible energy-rich compounds (Dormaar and Sauerbeck 1983), the $A h_{2}$ contains the more mature root mass, therefore leading to more polysaccharides of plant origin. Similarly, the $\mathrm{Ah}_{2}$ and $\mathrm{Bm}$ horizons of the cropland would represent straw worked into the soil (Doughty 1948), again leading to more polysaccharides of plant origin.

Simple phenols, benzoic acid, and derivatives are the most commonly identified allelopathic compounds produced by higher plants that may inhibit plant growth and nutrient uptake (Rice 1984). Phenolic acids also have been reported to either suppress indole-3-acetic acid (IAA) or to stimulate IAA oxidase (Lee et al. 1982). To take this one step further, Lee (1977) has shown that aliphatic and aromatic carboxylic acids may cause the loss, through changes in the root permeability, of ions such as $\mathrm{K}^{+}, \mathrm{Ca}^{++}$, and $\mathrm{NO}_{3}-\mathrm{N}$, and ultraviolet-absorbing materials into the surrounding solution.

Since, among others, hydrocinnamic acid (peak 5), p-hydroxybenzoic acid (peak 6), syringic acid (peak 12), p-coumaric acid (peak 13), and ferulic acid (peak 15) are all phytotoxic towards germination with even stronger effects on the growth of seedlings (Hennequin and Juste 1967), it may be hypothesized that the significantly greater quantities of these and others in the blue grama soil compared with the needle-and-thread/blue grama soil are an example of allelopathy being a factor in ecological process (Muller 1969). p-Coumaric and ferulic acids also have been reported to affect plant-water relationships (Einhellig et al. 1985). At this point it is not possible to state if these acids came from the blue grama or from little club-moss. Nevertheless, little else grows when these 2 species are present. Both increased in prominence because of excessive grazing pressures (Coupland 1961, Smoliak et al. 1972), yet this community still exists in spite of being only moderately grazed at present. Water extracts of roots of blue grama, simulating water through-flow, also inhibit the oxidation of ammonia to nitrate (Neal 1969). Ferulic acid is a unit compound in the synthesis of lignin, and its increased presence in the cropland soil thus may be due to the incorporation of the straw into the soil.

In range ecology, it is often generalized that given the right conditions, such as stocking rate or rest rotation, plant succession will automatically follow. If the allelopathic effect is valid under blue grama/little club-moss by preventing plant succession, this may then present a challenge to the range manager. On the whole, range recovery, particularly under semiarid climatic conditions, is poorly understood and defined:

Of course, the organic acids identified were obtained via the more drastic $\mathrm{NaOH}$-extraction. Nevertheless, the suite of acids tentatively identified do give an indication of the presence of these compounds in the soil organic matter and thus, the potential for their effect in the overall biochemical processes in the soil. From a range management point of view, the higher amounts of acids identified in the blue grama Ah horizons may further exacerbate this potential. At this point it is not possible to say if this is for better or for worse.

Most identified acids were present in all horizons. Since the quantitative fingerprints were different from horizon to horizon and soil to soil, it does demonstrate complex and interrelated effects among soil horizons, plant species, and management. Although the selection of the blue grama soil may indeed be extreme when used in paired comparison with cultivated soil, it does emphasize the dilemma of selecting baseline soils for management comparisons, particularly since exclosure soils represent another extreme in relation to pre-range management times. 


\section{Literature Cited}

Alberta Agriculture. 1984. Alberta fertilizer guide. Agri-Fax 1. Agdex 541-1.

Coupland, R.T. 1961. A reconsideration of grassland classification in the Northern Great Plains of North America. J. Ecol. 49:135-167.

Dormaar, J.F. 1964. Fractionation of the humus of some Chernozemic soils of southern Alberta. Can. J. Soil Sci. 44:232-236.

Dormaar, J.F. 1984. Monosaccharides in hydrolysates of water-stable aggregates after 67 years of cropping spring wheat as determined by capillary gas chromatography. Can. J. Soil Sci. 64:647-656.

Dormaar, J.F. 1987. Quality and value of wind-movable aggregates in Chernozemic Ap horizons. Can. J. Soil Sci. 67:601-607.

Dormagr, J.F. 1988. Effect of plant roots on chemical and biochemical properties of surrounding discrete soil zones. Can. J. Soil Sci. 68:233-242.

Dormaar, J.F., and U.J. Pittman. 1980. Decomposition of organic residues as affected by various dryland spring wheat-fallow rotations. Can. J. Soil Sci. 60-97-106.

Dormaar, J.F., and D.R. Sauerbeck. 1983. Seasonal effects on photoassimilated carbon-14 in the root system of blue grama and associated soil organic matter. Soil Biol. Biochem. 15:475-479.

Dormaar, J.F., and S. Smoliak. 1985. Recovery of vegetative cover and soil organic matter during revegetation of abandoned farmland in a semiarid climate. J. Range Manage. 38:487-491.

Dormagr, J.F., A. Johnston, and S. Smoliak. 1977. Seasonal variation in chemical characteristics of soil organic matter of grazed and ungrazed mixed prairie and fescue grassland. J. Range Manage. 30:195-198.

Dormar, J.F., S. Smoliak, and A. Johnston. 1981. Seasonal fluctuations of blue grama roots and chemical characteristics. J. Range Manage. 34:62-64.

Doughty, J.L. 1948. The maintenance of organic matter in the Brown soils. Sci. Agr. 28:88-95.

Doutre, D.A., G.W. Hay, A. Hood, and G.W. VanLoon. 1978. Spectrophotometric methods to determine carbohydrates in soil. Soil Biol. Biochem. 10:457-462.

Dubois, M., K.A. Gilles, J.K. Hamilton, P.A. Rebers, and F. Smith. 1956. Colorimetric method for determination of sugars and related substances. Anal. Chem. 28:350-356.

Einhellig, F.A., M. Stille Muth, and M.K. Schon. 1985. Effects of allelochemicals on plant-water relationships. p. 179-195. In: A.C. Thompson (ed.), The chemistry of allelopathy. ACS Symposium Series 268. Amer. Chem. Soc., Washington, DC.

Hamence, J.H. 1944. The detection and determination of auxins in organic manures. Part II.-Extraction of auxins from manures, and applications of the perchloric acid test for $\beta$-indolyl acetic acid and of the Went pea test. Analyst 69:229-235.

Hennequin, J.-R., and C. Juste. 1967. Presence d'acides phenols libres dans le sol. Etude de leur influence sur la germination et la croissance des vegetaux. Ann. Agron. 18:545-569.

Jalal, M.A.F., and D.J. Read. 1983. The organic acid composition of Calluna heathland soil with special reference to phyto-and fungitoxicity. I. Isolation and identifications of organic acids. Plant Soil 70:257-272.
Keeney, D.R. 1982. Nitrogen-Availability indices. In: A.L. Page (ed.). Methods of soil analysis. Part 2. Chemical and microbiological properties. Agron. 9:711-733. Amer. Soc. Agron., Madison, Wisc.

Keeney, D.C., and D.W. Nelson. 1982. Nitrogen-Inorganic forms. In: A.L. Page (ed.). Methods of soil analysis. Part 2. Chemical and microbiological properties. Agron. 9:643-698. Amer. Soc. Agron., Madison, Wisc.

Lee, R.R. 1977. Effects of organic acids on the loss of ions from barley roots. J. Exp. Bot. 28:578-587.

Lee, T.T., A.N. Starratt, and J.J. Jevnikar. 1982. Regulation of enzymic oxidation of indole-3-acetic acid by phenols: Structure-activity relationships. Phytochemistry 21:517-523.

MacKay, D.C., and J.M. Carefoot. 1981. Control of water content in laboratory determination of mineralizable nitrogen in soils. Soil Sci. Soc. Amer. J. 45:444-446.

Morita, H. 1965. The phenolic acids in organic soils. Can. J. Biochem. 43:1277-1280.

Muller, C.H. 1969. Allelopathy as a factor in ecological process. Vegetatio 18:348-357.

Neal, J.L., Jr. 1969. Inhibition of nitrifying bacteria by grass and forb root extracts. Can. J. Microbiol. 15:633-635.

Oades, J.M. 1984. Soil organic matter and structural stability: Mechanisms and implications for management. Plant Soil 76:319-337.

Olsen, S.R., C.V. Cole, F.S. Watanabe, and L.A. Dean. 1954. Estimation of available phosphorus in soils by extraction with sodium bicarbonate. Circ. No. 939. USDA, Washington, DC.

Pierce, Chemical Company. 1985. Pierce 1985-86 handbook and general catalogue. Rockford, Ill.

Rice, E.L. 1984. Allelopathy. 2nd ed. Academic Press, Inc., New York, NY. Ridley, A.O., and R.A. Hedlin. 1968. Soil organic matter and crop yields as influenced by the frequency of summer fallowing. Can. J. Soil Sci. 48:315-322.

Ross, D.J. 1971. Some factors influencing the estimation of dehydrogenase activities of some soils under pasture. Soil Biol. Biochem. 3:97-110.

Russell, E.W. 1961. Soil conditions and plant growth. 9th ed. Longmans, Green and Co. Ltd., London, England.

Smoliak, S., J.F. Dormar, and A. Johnston. 1972. Long-term grazing effects on Stipa-Bouteloua prairie soils. J. Range Manage. 25:246-250.

Steel, R.G.D., and J.H. Torrie. 1980. Principles and procedures of statistics: a biometrical approach. 2nd ed. McGraw Hill Book Co., Toronto, Ont.

Vance, G.F., S.A. Boyd, and D.L. Mokma. 1985. Extraction of phenolic compounds from a Spodosol profile: An evaluation of three extractants. Soil Sci. 140:412-420.

Whitehead, D.C., H. Buchan, and R.D. Hartley. 1975. Components of soil organic matter under grass and arable cropping. Soil Biol. Biochem. 7:65-71.

Windholz, M., S. Budavari, R.F. Blumetti, and E.S. Otterbein. 1983. The Merck Index. 10th ed. Merck \& Co., Inc., Rahway, NJ. 